\title{
Correlation Parenting Styles with Children's Health Behaviors during Pandemic COVID-19 at MI Nurul Huda Wadeng Gresik
}

\section{Chilyah Faiqotun Nuriyah ${ }^{{ }^{*}}$, Lantin Sulistyorini ${ }^{2}$, Peni Perdani Juliningrum ${ }^{3}$}

${ }^{1 *}$ Faculty of Nursing, University of Jember, Indonesia; chilyahselly@gmail.com (Corresponding Author)
2,3Department of Pediatric Health Care Research, Faculty of Nursing, University of Jember, Indonesia

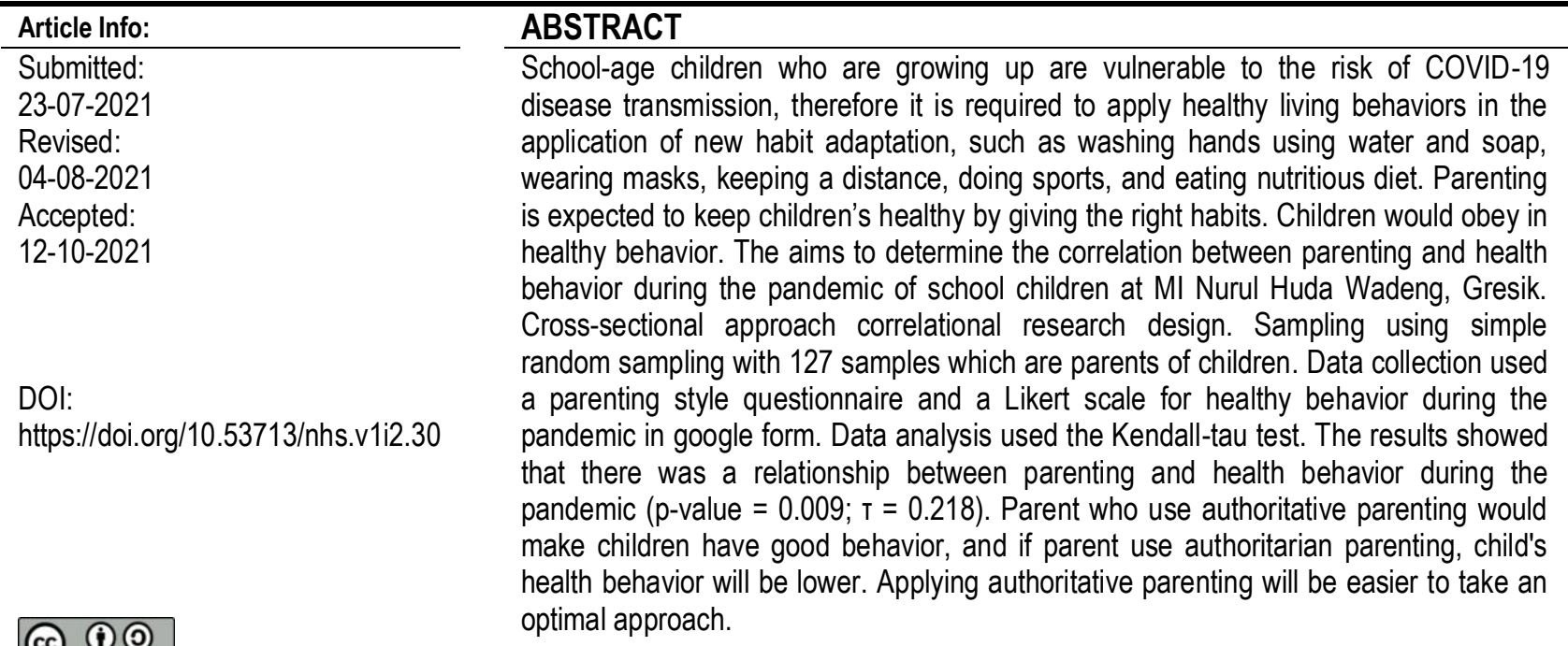

This work is licensed under CC BY-SA License.
Keywords: parenting styles; children pandemic behaviors; authoritative; authoritarian; permissive

\section{INTRODUCTION}

The COVID-19 pandemic in Indonesia has an impact on the lives of various sectors as well as among children to the elderly, health behavior is needed as an effort to avoid the risk of transmission the disease, considering that school children are in their growing period and groups of children are vulnerable to the risk of transmission of COVID-19 disease (Anggraeni, 2020). Healthy living behavior in the application of new habit adaptations, such as washing hands using water and soap, wearing masks, maintaining distance, being active in sports, and eating nutritious diet (Kemenkes, 2020). Problems in health behavior that occur in school children in general forgetting to wash their hands after activities (Alfitra, 2017), don't like eating vegetables, and don't throw trash in its place (Hendrawati et al, 2020). Therefore, children will be at risk of being infected with diseases caused by poor health behavior, it is feared will be increase the incidence of infectious disease (UNICEF, 2020), especially during the pandemic, they are at risk of being exposed to COVID-19 (Maulidia and Hanifah, 2020).

The prevalence in the USA is $14 \%$ deteriorating health behavior in children. $48 \%$ missing regular child care during the pandemic and lack of food security to meet children's nutritional needs (Patrick et al., 2020). Child compliance with health behavior during the pandemic was 7,43\% (Saurabh \& Ranjan, 2020). In Indonesia, the prevalence of hand washing behavior according to school age is still $59 \%, 85 \%$ of school age children consume less fruit and vegetables, and $58,61 \%$ it is difficult to implement social distancing. There is also $49,3 \%$ of poor compliance in adapting new habits during the pandemic (Fadilah, 2020). Researchers have made observations at the study site on 10 children and got the results that 7 children did not wear masks and 1 child wore masks incorrectly, 6 children did not wash their hands before or after eating the newly purchased snacks and 10 children did not wash their hands correctly. 6 children have kept their distance and avoided crowds by playing less outside and more often indoors, 6 children stated that they do not like eating vegetables, and only 3 children often exercise by morning walks and cycling.

One of the factors that influence the healthy behavior of school children is parents, this is related to the intense relationship between children and parents who have a lot of time to interact (Nugraheni, 2018). Parenting is the most dominant and basic parental behavior in daily childcare, parenting applied by parents will affect the behavior and 
discipline of children. Parents are required to be able to maintain the health of their children during the pandemic so that children stay healthy. Therefore, the parenting style used by parents is expected to be able to maintain the health of their children by habituation so that children are obedient in healthy living behaviors (Anhusadar and Islamiyah, 2020). Based on the description above. Therefore, researchers are encouraged to carry out research on the relationship between patterns of foster parents with health behavior during the pandemic of school-age children at MI Nurul Huda Wadeng Gresik, that later they can find out the relationship and improve the quality of nursing services by developing adequate further service strategies from the research results obtained.

\section{METHOD}

This research aims to Knowing the relationship between parenting patterns and behavior health during the pandemic COVID-19 school children at Madrasah Ibtidaiyah (MI) Nurul Huda Wadeng, Gresik. The design of this study is quantitative correlation with a cross-sectional approach. The sampling technique is simple random sampling using a digital random lottery application. The number of samples used were 127 parents of school children. The data collection technique uses a parenting style questionnaire from Jannah's research (2017) which has been tested for validity 0,343 0,793 and reliability 0,616 . Then also use the Likert scale for healthy behavior during the COVID-19 pandemic from Yanti (2020) which has been tested for validity $0,318-0,783$ and reliability 0,679 . The questionnaire was distributed of a google form via whatsapp for one week. Then the results of the data were analyzed univariate and bivariate using the Kendall-Tau test to produce frequencies and percentages. This research has complied with research ethics that has been tested by KEPK FKep Unej with No. 77/UN25.1.14/KEPK/2021.

\section{RESULT}

\section{Characteristics of Respondents}

Table 1. Distribution of respondents based on gender, education, occupation, religion, ethnicity, and class level of children at Ml Nurul Huda Wadeng Gresik, $2021(n=127)$

\begin{tabular}{|c|c|c|}
\hline Variable & Frequency & $\%$ \\
\hline \multicolumn{3}{|l|}{ Gender } \\
\hline Man & 20 & 15.7 \\
\hline girl & 107 & 84.3 \\
\hline \multicolumn{3}{|l|}{ Education } \\
\hline Primary School & 22 & 17.3 \\
\hline Junior high school & 15 & 11.8 \\
\hline Senior high school & 72 & 56.7 \\
\hline Bachelor & 17 & 13.4 \\
\hline Master & 1 & 0.8 \\
\hline \multicolumn{3}{|l|}{ Profession } \\
\hline Private employees & 6 & 4.7 \\
\hline Teacher & 19 & 15.0 \\
\hline self-employed & 15 & 11.8 \\
\hline Entrepreneur & 1 & 0.8 \\
\hline Laborer & 5 & 3.9 \\
\hline Housewife & 81 & 63.8 \\
\hline \multicolumn{3}{|l|}{ Children's Classes } \\
\hline Grade 1 & 20 & 15.7 \\
\hline Grade 2 & 20 & 15.7 \\
\hline Grade 3 & 24 & 18.9 \\
\hline Grade 4 & 24 & 18.9 \\
\hline Grade 5 & 15 & 11.8 \\
\hline Grade 6 & 24 & 18.9 \\
\hline \multicolumn{3}{|l|}{ Religion } \\
\hline Muslim & 127 & 100.0 \\
\hline Non-Muslim & 0 & 0 \\
\hline \multicolumn{3}{|l|}{ Tribe } \\
\hline Java & 127 & 100.0 \\
\hline non-java & 0 & 0 \\
\hline
\end{tabular}

Table 2. Distribution of respondents based on parental age and child class level at MI Nurul Huda Wadeng Gresik, $2021(n=127)$ 


\begin{tabular}{ccc}
\hline Variable & Median & Min-Max \\
\hline Age (years) & 37.00 & $27-52$ \\
\hline
\end{tabular}

The results showed that 127 respondents were all Muslim and Javanese. Based on gender, the most female parents who participated in the study were 107 respondents $(84,3 \%)$ with the average age of the parents is 37,54 years and the age range of the respondents is $27-52$ years. The most recent parent education is senior high school graduates with a total of 72 respondents $(56,7 \%)$. Based on occupation, the most respondents did not work or take care of the housewife with a total of 81 respondents $(63,8 \%)$ and followed by the profession as a teacher with 19 respondents $(15 \%)$. Meanwhile, the highest number of children who participated in the study were in grades 3 and 4 , each of which amounted to $24(18,9 \%)$.

\section{Overview of Parenting Styles}

Table 3. Frequency of parenting styles by parents to school children at MI Nurul Huda Wadeng Gresik, $2021(n=127)$

\begin{tabular}{lccc}
\hline & Variable & Frequency & $\%$ \\
\hline Authoritarian & 21 & 16.5 \\
Authoritative & 95 & 74.8 \\
Permissive & 11 & 8.7 \\
\hline \multicolumn{2}{c}{ Total } & 127 & 100.0 \\
\hline
\end{tabular}

The results of the study found that Parenting patterns have a tendency to authoritative parenting as much as $74,8 \%$. While Parents who have authoritarian parenting are $16,5 \%$ and the least is permissive parenting which is $8,7 \%$.

\section{Overview of Health Behavior During Pandemic School Children}

Table 4. Frequency of health behavior during the pandemic of school children at MI Nurul Huda Wadeng Gresik, $2021(n=127)$

\begin{tabular}{ccc}
\hline \multicolumn{1}{c}{ Variable } & Frequency & $\%$ \\
\hline Low Health Behavior & 19 & 15.0 \\
Moderate Health Behavior & 84 & 66.1 \\
Good Health Behavior & 24 & 18.9 \\
\hline Total & 127 & 100.0 \\
\hline
\end{tabular}

The most dominant health behavior during the COVID-19 pandemic for school-age children was moderate health behavior at $66,1 \%$. The children who have good health behavior during the pandemic are $18,9 \%$ and the low category health behavior is $15 \%$.

\section{Analysis of The Relationship of Parenting Patterns with Health Behavior during the Pandemic of School Children at MI Nurul Huda Wadeng Gresik}

Table 5. The Relationship between Parenting Patterns and Behavior during the Pandemic of School Children at MI Nurul Huda Wadeng Gresik

\begin{tabular}{lccccc}
\hline \multirow{2}{*}{ Variable } & \multicolumn{2}{c}{ Health Behavior During Pandemic School Children } & \multirow{2}{*}{$\mathrm{p}$-value } & $\mathrm{T}$ \\
\cline { 1 - 4 } \multicolumn{1}{c}{ Parenting Styles } & Low & Currently & Good & & \\
\cline { 1 - 3 } Authoritarian & $6(4.7 \%)$ & $14(11 \%)$ & $1(0.8 \%)$ & & \multirow{2}{*}{0.218} \\
Authoritative & $12(9.4 \%)$ & $64(50.4 \%)$ & $19(15 \%)$ & & \\
Permissive & $1(0.8 \%)$ & $6(4.7 \%)$ & $4(3.1 \%)$ & & \\
\hline
\end{tabular}

Correlational statistical test found that there is a relationship between parenting patterns and health behavior during the COVID-19 pandemic for school-age children at MI Nurul Huda Wadeng Gresik with a value ( $p$-value $=0.009)$ and shows the direction of a positive relationship which has a weak strength value $(\mathrm{T}=0.218)$. 
The results of the study stated that there was a relationship between parenting patterns and health behavior during the pandemic of school children ( $p$-value $<0,05$ ). This is in accordance with the research presented by Anhusadar (2021), that the success of healthy living behavior as an effort to break the chain of the COVID-19 pandemic is based on cohesiveness, of course the cohesiveness of the family (parents and children). Parents must be united and motivate their children to carry out health behaviors during the pandemic. Even though the pandemic period will end, at least there will be positive things for parents and children, namely the growth of positive and entrenched health behaviors in trying to keep themselves and their environment healthy.

In a study written by Machmud, Koencaraningrat said that the shape of the patternhParental care is very closely related to the character of a child until the child becomes an adult. This is because the character or behavior of an adult individual has actually embedded the seeds into the soul of an individual since childhood. Behavior is also determined by the way children are taught to eat, clean, disciplined, taught to play and socialize (Machmud, 2021). That the researchers concluded that the pattern of_Parenting used by parents is very dominant in shaping the behavior of children from childhood to adulthood. Likewise, Clemes Haris said that children's behavior will gradually shape their character, provide direction, and strengthen children's behavior in the same circumstances in life (Machmud, 2021). Therefore, the researcher assumes that the role of parents is as a supervisor for their family members from the transmission of the covid-19 virus by providing education and examples to family members, including children. How to use masks, both surgical masks and cloth masks, the application of healthy living behavior, that to prevent children and all family members from transmitting the Covid- 19 virus.

Looking at the kendall-tau correlation value $(\mathrm{T})$ which shows 0.218 , which means the direction of the relationship shows a positive value with weak strength, which means that parents who increasingly use authoritative parenting patterns will have good health behavior during the pandemic, and vice versa if they increasingly apply this pattern. harsh or authoritarian parenting, the lower the child's health behavior. This is in line with previous research which stated that,Parents as the closest environment for children must understand how to properly raise children in fostering healthy lifestyle habits in children. Patternhlnappropriate parenting will have an impact on the feeling of discomfort and even rejection of the child. Positive parenting patterns that include affection,pUnderstanding, and respecting children will make children feel close and willing to respond well to the stimulation given (Wiranata, 2020). That according to the researcher, applying authoritative parenting will encourage parents to enter the child's world so that it will be easier to carry out an optimal approach. Children will feel close to their parents and make them as role models or role models in behavior.

PatternhParenting that is possible to maintain harmony, affection, and firmness of parents to children is authoritative parenting. Children will feel close to their parents and make them as role models in behavior. During the pandemic, parental authoritative parenting for children can be realized in the form of maintaining children's health, assisting children to learn online, taking time for joint activities, creating a safe and comfortable environment, establishing intense communication with children, and conducting variations and innovations in activities at home (Dewi, 2020).

\section{CONCLUSION}

The conclusion of this study is that there is a relationship between parenting and health behavior during the COVID-19 pandemic for school-age children at MI Nurul Huda Wadeng Gresik ( $p$-value $=0,009$ ) and shows the direction of a positive relationship which has a weak strength value $(\tau=0,218)$ which means that parents who increasingly use authoritative parenting will have good health behavior during the pandemic, and if the more strict or authoritarian parenting is applied, the lower the child's health behavior. Respondents and other communities should be able to apply authoritative parenting so that they can improve health behavior during the pandemic in children as an effort to prevent infection transmission during the pandemic.

\section{ACKNOWLEDGEMENT}

Researchers would like to thank all parties involved who have contributed to this research, one of which is the school and parents of MI Nurul Huda Wadeng school children Gresik Regency who have collaborated well and this research can be carried out smoothly and runs well.

\section{REFERENCES}


Alfitra, A. (2017). The role of parents in compliance with hand washing with soap in school-age children. Thesis. Jombang: Undergraduate Nursing Study Program Stikes Insan Cendekia Medika.

Anggraini, DT and R. Hasibuan. (2020). An overview of the promotion of PHBS in supporting a healthy lifestyle for the people of Binjai City during the COVID-19 pandemic in 2020. Menara Medika. 3(1), 22.

Anhusadar, L. and I. Islamiyah. (2020). The application of clean and healthy behavior for early childhood in the midst of the covid-19 pandemic. Obsession Journal: Journal of Early Childhood Education. 5(1), 463-475.

Dewi, PASC and H.Khotimah. (2020). Parenting Patterns for Children in the Covid-19 Pandemic Period. SENASIF: National Seminar on Information Systems. Faculty of Information Technology UNMER Malang.

Fadilah, M., Pariyana, S. Aprilia, and RA Syakurah. (2020). Evaluation of Community Compliance in Adapting New Habits Based on the Health Belief Model. AVOER 12.

Hendrawati, S., U. Rosidin, and S. Astiani. (2020). Clean and healthy living behavior (PHBS) of students in state junior high schools (SMPN). Indonesian Journal of Nurses. 4(1), 54-66.

Jannah, MM. (2017). Identification of Parenting Patterns in ABA Kindergarten Jogokaryan Yogyakarta. Journal of Early Childhood Education. 6(6), 547-552.

Indonesian Ministry of Health. (2020). Guidelines for the Prevention and Control of Corona Virus Disease 2019. Citing Internet sources URL https://covid19.kemkes.go.id/protokol-covid-19/kmk-no-hk-01-07-menkes-413-2020-ttg-pedomanpentahanan-dan-control-covid-19/

Indonesian Ministry of Health. (2020). Towards New Adaptations. Directorate of Health Promotion and Community Empowerment. Citing internet sources URLhttps://promkes.kemkes.go.id/menuju-adaptasi-kecepatan-baru

Machmud, H. (2021). Framing Children's Personality with Parenting Patterns during the Covid-19 Period. MURHUM: Journal of Early Childhood Education. 2(1), 44-55.

Maulidia, A. and U. Hanifah. (2020). The role of parental education for PHBS AUD during the covid-19 pandemic. Musamus Journal of Primary Education. 3(1), 35-44.

Nugraheni, H., S. Indarjo, and Suhat. (2018). School-Based Health Promotion Textbook. Yogyakarta: Depublish.

Patrick, SW, LE Henkhaus, JS Zickafoose, K. Lovell, A. Halvorson, S. Loch, M. Letterie, and MM Davis. (2020). Well-being of parents and children during the covid-19 pandemic: a national survey. Pediatrics. 146(4), 1-8.

Saurabh, K. and S. Ranjan. (2020). Compliance and Psychological Impact of Quarantine in Children and Adolescents due to Covid19 Pandemic. The Indian Journal of Pediatrics. 87(7), 532-536.

UNICEF. (2020). COVID-19 and children in Indonesia action agenda to address socio-economic challenges. Journal of Education, Psychology and Counseling. 2(April), 1-12.

Wiranata, IGLA. (2020). Application of Positive Parenting in Habituation of a Clean and Healthy Lifestyle for Early Childhood. Pratama Widya: Journal of Early Childhood Education. 5(1), 82-88.

Yanti, NPED, IMADP Nugraha, GA Wisnawa, NPD Agustina, and NPA Diantari. (2020). Description of Public Knowledge about Covid-19 and Community Behavior during the Covid-19 Pandemic. Journal of Mental Nursing. 8(3), $485-490$. 